\title{
Supplying Carbon Sequestration From West African Rangelands: Opportunities and Barriers
}

\author{
Leslie Lipper, ${ }^{1}$ Celine Dutilly-Diane, ${ }^{2}$ and Nancy McCarthy ${ }^{3}$
}

Authors are ${ }^{1}$ Senior Environmental Economist, Food and Agriculture Organization of the United Nations, Rome, Italy 00153; ${ }^{2}$ Socio-Economist, Centre de Coopération Internationale en Recherche Agronomique pour le Développement Systèmes d'élevage, Montpellier, F-34398, France; and ${ }^{3}$ Senior Analyst, Environmental Law and Economics, Food and Agriculture Organization of the United Nations, Rome, Italy 00153.

\begin{abstract}
The emergence of markets for mitigation of climate change presents new opportunities for increasing economic and ecological returns to rangelands in developing countries. Improving rangeland management is a potentially significant source of mitigation from sequestration. It is appealing due to the likely links to sustainable agricultural development and poverty reduction. Many of the changes needed to sequester carbon are also associated with improved rangeland productivity and incomes. We provide an overview of the key issues that arise in determining the potential of carbon markets to support improved rangeland management focusing on West Africa, an area where pastoralism is a major economic activity with extensive rangelands that offer considerable potential for sequestering carbon. Estimates of the potential for increasing sequestration through improved rangeland management are summarized. Per hectare amounts are low, but aggregate potential is high. Carbon emission reductions are generated by reducing or avoiding land degradation, rehabilitating degraded lands, and increasing native carbon stocks by increasing aboveground and belowground biomass. Avoiding degradation and rehabilitating lightly degraded lands are the least costly and can generate significant carbon emission reductions. Carbon offsets from agricultural sources are currently limited under regulatory cap and trade regimes, and prices in voluntary markets are relatively low. Low returns to carbon offsets per hectare mean that significant cobenefits in the form of increased rangeland productivity and incomes would be necessary to induce participation. High transactions costs can be a problem in carbon markets and in adopting improved rangeland management practices, highlighting the need for institutions to provide effective coordination, monitoring, and enforcement. Evidence from Burkina Faso suggests the potential for existing local-level institutions to play an important role in future carbon payment programs, should they emerge.
\end{abstract}

\section{Resumen}

La emergencia de mercados para la mitigación del cambio climático presenta nuevas oportunidades para incrementar los retornos económicos y ecológicos de pastizales naturales en países en vías de desarrollo. El mejoramiento del manejo de pastizales es una fuente potencialmente significativa de mitigación a través del secuestro de carbono. Esta es una opción atractiva por sus probables conexiones con el desarrollo de agricultura sustentable y la reducción de la pobreza. Muchos de de los cambios requeridos para el secuestro de carbono están también asociados con el mejoramiento de la productividad de los pastizales y de los ingresos. Proveemos una reseña de los asuntos clave que surgen en la determinación de mercados potenciales de carbono para mantener mejoras en el manejo de los pastizales haciendo énfasis en África Occidental, un área en el que el pastoralismo es una actividad económica de envergadura y que cuenta con superficies extensas de pastizales naturales que ofrecen un potencial considerable para el secuestro de carbono. Se resumen las estimaciones del potencial para incrementar el secuestro de carbono a través de mejoras en el manejo de los pastizales. Las cantidades por hectárea son bajas, pero el potencial acumulado de la región es alto. Las reducciones en emisiones de carbono se logran a través de la disminución o evitación de la degradación de la tierra, la rehabilitación de áreas degradadas, y el incremento de stocks nativos de carbono incrementando la biomasa aérea y subterránea. La evitación de la degradación y la rehabilitación de tierras levemente degradas son las estrategias menos costosas, y pueden generar disminuciones significativas en la emisión de carbono. Las compensaciones de carbono de fuentes agrícolas están limitadas actualmente por las regulaciones de los regímenes de "cap and trade" y los precios en mercados voluntarios son relativamente bajos. Los retornos bajos de compensación de carbono por hectárea hacen que sean necesarios incrementos significativos en la productividad del pastizal y los ingresos para inducir participación. Los altos costos de transacción pueden ser un problema en los mercados de carbono y en la adopción de prácticas que mejoren el manejo de los pastizales, subrayando la necesidad de que las instituciones provean coordinación, monitoreo, y aplicación efectiva. La evidencia de Burkina Faso sugiere que, de emerger, existe el potencial para que instituciones locales jueguen un rol importante en el futuro de los programas de comercialización de carbono.

Key Words: carbon sequestration, climate change, rangeland management

Research was funded in part by the Food and Agriculture Organization of the United Nations

This publication was made possible through support provided to the Global Livestock Collaborative Research Support Program by the Office of Agriculture, Bureau for Economic Growth, Agriculture and Trade, United States Agency for International Development under terms of Grant No. PCE-G-00-98-00036-00. The opinions expressed herein are those of the author(s) and do not necessarily reflect the views of the USAID.

Correspondence: Leslie Lipper, Senior Environmental Economist, Agriculture and Development Economics Division, Food and Agriculture Organization of the United Nations, Rome, Italy 00153. Email: leslie.lipper@fao.org

Manuscript received 19 January 2009; manuscript accepted 21 October 2009. 


\section{INTRODUCTION}

The emergence of markets for climate change mitigation presents new opportunities for increasing the economic and ecological returns to rangelands and pasturelands in developing countries. One means of reducing net carbon emissions is to increase the rate of carbon sequestered in terrestrial ecosystems, including in soils and above-ground biomass. Implemented on a large scale, rangeland management improvement is a potentially significant source of mitigation (Intergovernmental Panel on Climate Change [IPCC] 2007). Data on the potential of changes to rangelands management to reduce net greenhouse gas (GHG) emissions are relatively scarce; however, studies indicate that gains in sequestration could be significant (Conant and Paustian 2002; Lal 2002; Batjes 2004; Woomer et al. 2004; IPCC 2007). Generating carbon sequestration from rangelands is appealing due to the potential links to sustainable agricultural development and poverty reduction (Conant and Paustian 2002; Batjes 2004; Food and Agriculture Organization [FAO] 2006). In West Africa, declining rangeland productivity and returns to agricultural production together with population growth has resulted in high levels of poverty and food insecurity (Okai 1997). Practices that sequester carbon may also result in increased agricultural incomes over time, by increasing the productivity and net returns to the livestock production system. Reduced emissions and greater sequestered carbon is thus a positive externality generated from many of the changes in production practices desirable from an agricultural development standpoint. Payments for this service via carbon financial mechanisms could be a means of supporting changes in West Africa that yield benefits to local livelihoods, as well as the global environment. However, there are several hurdles to overcome. Better information on the benefits and costs of making the necessary changes in management practices as well as their potential for reducing emissions over space and time are needed to assess where, how, and how much potential can be realized. Improving institutional capacity is key, since both changes in management practices and making payments for emission reductions require coordination, monitoring, and enforcement. Developing strategies and links to sources of carbon finance that can be tailored to fit the needs of rangelands producers is also needed, with relatively little experience on the ground so far.

This paper is organized as follows: in the following section we summarize the literature on the technical potential of rangelands to supply carbon sequestration and the opportunity costs involved, focusing specifically on West Africa. The following section discusses the current potential for payments for carbon sequestration from rangelands and prices paid. Next, we discuss effective carbon offsets payments programs, considering the specific agro-ecological and socioeconomic context of the West African area. We present data from a survey of community-based natural resource management projects in Burkina Faso to illustrate local capacity already in place as well as issues for effective institutional design for carbon sequestration payments. The paper concludes with a discussion on the implications of the findings for carbon sequestration payments to rangeland producers in the West African Sahel.

\section{POTENTIAL FOR SUPPLYING CARBON SEQUESTRATION FROM WEST AFRICAN RANGELANDS}

\section{Why Consider Sequestering Carbon in West African Rangelands?}

There are two main reasons for looking into the potential of sequestering carbon from West African rangelands: 1) degradation and depletion of carbon stocks in these systems has resulted in declining rangeland and agricultural productivity, which in turn reduces the livelihood capacity of the local population and leads to impoverishment (Batjes 2004; Tieszen et al. 2004); and 2) increasing carbon stocks in the system can be not only a way of improving the ecological health and productivity of the livestock systems, but also a significant and low-cost way of mitigating climate change (Woomer et al. 2004).

Rangelands have been defined as "land carrying natural or semi-natural vegetation which provides a habitat suitable for herds of wild or domestic ungulates" (Homewood 2004, p. 126). These include grasslands, bush, woodland, and croplands depending on biophysical and socioeconomic conditions (Homewood 2004). Globally, rangelands cover approximately $30 \%$ of global land area or 40 million $\mathrm{km}^{2}$, two-thirds of which are located in arid and semiarid areas (Le Houérou 2006). SubSaharan Africa is estimated to have a total of 12.8 million $\mathrm{km}^{2}$ of habitable drylands, divided between arid, semiarid, and dry subhumid zones, supporting a population of approximately 189 million people in 1994 (Swallow and McCarthy 2000). Data on rangelands for West Africa are difficult to find; in the mid-1970s the estimated area of rangelands was 2.9 million $\mathrm{km}^{2}$ (excluding deserts), $56 \%$ of which were located in the Sahelian zone (Boudet 1975).

In recent years, extensive livestock systems in Africa have been undergoing rapid changes due to several factors, including drought, population growth, and policies encouraging sedentarization of pastoralists, which has increased degradation on grazing lands in semiarid zones (Niamir-Fuller 1999). Degradation of grazing resources has contributed toward declining grazing and livestock productivity and increasing vulnerability of the livelihoods of pastoral-dependent populations. Improving the management of these grazing lands to reduce degradation is a primary means of improving the situation of some of the world's poorest peoples (Pratt 1997).

\section{Carbon Sequestration Potential From Rangelands}

The fourth IPCC assessment report indicates that improved grazing land management has the second highest technical potential for mitigating carbon emissions from agricultural management changes, at over $1400 \mathrm{Mt} \mathrm{CO}_{2}$ equivalent per year by 2030, entirely from carbon sequestration (IPCC 2007, p. 515).The world's grasslands store $200000-420000 \mathrm{Mt} \mathrm{C}$, a large part of which is below the soil surface (Robert 2001). Estimates show that about $2 \%$ of the global soil organic carbon (SOC) reserves are to be found in West Africa (Batjes 2001). 
Due to less favorable agro-ecological conditions, the average SOC density $\left(42-45 \mathrm{t} \mathrm{C} \cdot \mathrm{ha}^{-1}\right)$ measured to the depth of $1 \mathrm{~m}$ is lower than the average found for the whole of Africa (64-67 t $\left.\mathrm{C} \cdot \mathrm{ha}^{-1}\right)$. Scientists agree that the potential for sequestering carbon in soils (per unit area) decreases as annual precipitation decreases and as mean temperatures increase (Batjes 2001).

A study from Senegal found that total system carbon varies from $12 \mathrm{t} \mathrm{C} \cdot \mathrm{ha}^{-1} \cdot \mathrm{yr}^{-1}$ on degraded rangelands up to $31.2 \mathrm{t}$ $\mathrm{C} \cdot \mathrm{ha}^{-1} \cdot \mathrm{yr}^{-1}$ in lands covered by scrublands with scattered trees. Eighty-four percent of that carbon resides in SOC (Woomer et al. 2004). Similar figures are presented by Tiessen et al. (1998), who show a $20-30 \%$ difference in carbon storage in the upper $20-\mathrm{cm}$ layer between degraded and nondegraded savannas in an area of Senegal with $500-650 \mathrm{~mm}$ annual average rainfall. Most Sahelian grazing lands are considerably drier at 250-500-mm annual average rainfall levels. These lands have suffered much damage in the past $50 \mathrm{yr}$, due to increasing human population, advance of cropping onto marginal lands, overgrazing, and serious deforestation, mainly for firewood, all exacerbated by recurrent droughts (Suttie et al. 2005).

Conant and Paustian (2002) estimate a global potential carbon sequestration of $45.7 \mathrm{Mt} \mathrm{C} \cdot \mathrm{yr}^{-1}\left(16.7 \mathrm{Mt} \mathrm{C} \cdot \mathrm{yr}^{-1}\right.$ for the African continent) through cessation of overgrazing and implementation of moderate grazing intensities (Fig. 1) assuming rehabilitation on lands ranging from severely to lightly degraded. Most $(83 \%)$ carbon sequestration potential identified is located in areas that were lightly or moderately overgrazed. Only a very small amount is located in severely overgrazed grasslands, since these lands require heavier and more costly investments for their rehabilitation. As severity of degradation increases, erosion is likely to increase, resulting in a decrease of carbon sequestration potential as associated costs for rehabilitation increase (Conant and Paustian 2002). Noting that rehabilitation in many cases is not economically feasible, Batjes (2004) estimated the carbon sequestration from improving practices on only $10 \%$ of degraded grasslands in Africa would still generate a significant mitigation benefit: in the range of $13-28 \mathrm{Mt} \mathrm{C} \cdot \mathrm{yr}^{-1}$ (Batjes 2004).

\section{Options and Opportunity Costs of Supplying Carbon Sequestration From Rangelands}

Ringius (2002) identifies three management strategies for maintaining and increasing soil organic matter (SOM) and carbon sequestration in the soil: 1) preserving existing SOM levels, 2) restoring depleted stocks, and 3) enlarging the SOM above the natural carrying capacity.

Preventing Land Degradation. Dregne (1991) estimated that around $53 \%$ of Africa's rangelands are moderately to severely degraded. Land degradation can lead to carbon emissions by reducing aboveground biomass as well as reducing soil carbon. Estimates of global impacts from various aspects of degradation are still under study, and in some cases significant differences in opinion exist (see, for example, Oost et al. 2007). Nonetheless site estimates of carbon losses associated with degradation do indicate a potentially significant emission reduction potential from reducing degradation (Ringius 2002; Reid et al. 2004; Woomer et al. 2004) Since rangeland restoration costs increase sharply with the severity of the

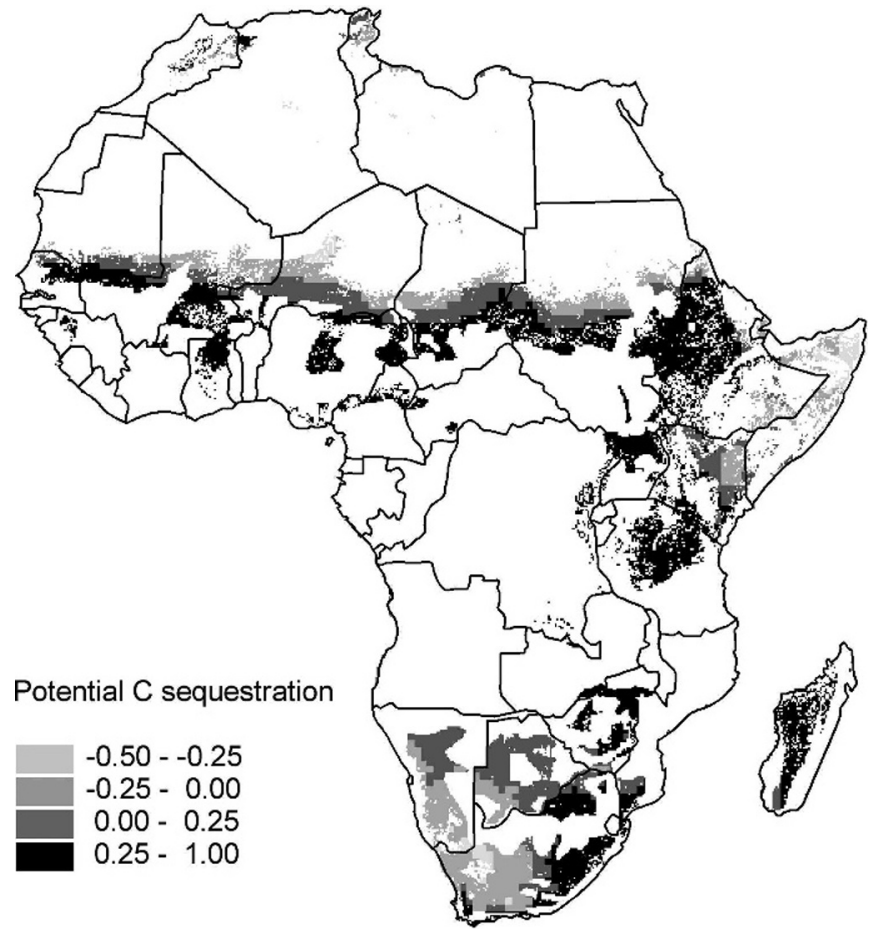

Figure 1. Potential annual carbon (C) sequestration ( $\mathrm{Mg} \mathrm{C}$. $\mathrm{ha}^{-1} \cdot \mathrm{yr}^{-1}$ ) from cessation of overgrazing and implementation of moderate grazing intensities. Increasing potential signified by increasingly darker shading. Source: Conant and Paustian (2002).

degradation level (Ojima et al. 1993), and carbon losses from rangeland degradation are estimated to be significant, better protection of current carbon stocks on rangelands should be a priority. A leading cause of land degradation on natural grazing land is the encroachment of croplands. When rangelands are converted to cropland, $95 \%$ of the aboveground carbon, and up to $50 \%$ of the belowground can be lost (Reid et al. 2004). For example, Ringius (2002) finds that in degraded semiarid savannas, soil carbon levels decreased by $40 \%$ in $3-5$ yr on sandy and in 5-10 yr on clay soils as a result of cultivation.

Tennigkeit and Wilkes report an average rate of $0.48 \mathrm{t}$ $\mathrm{CO}_{2} \mathrm{e} \cdot \mathrm{ha}^{-1}$ gain in sequestration from conversion of croplands to permanent pasture, based on a database of 38 data points gathered from studies throughout the world (Tennigkeit and Wilkes 2008). One estimate of average income generated by conversion to cropland from Burkina Faso is around US $\$ 50 \cdot \mathrm{ha}^{-1} \cdot \mathrm{yr}^{-1}$, albeit with highly variable returns over time and locations (Drabo et al. 2006). This implies the need for a price of $\$ 104 \cdot \mathrm{CO}_{2} \mathrm{e}^{-1}$ in order to compensate full opportunity costs that producers face, considerably higher than current market prices for this source of mitigation.

Fuel wood harvesting and wildfires are two other important causes of rangeland degradation. Woomer et al. (2004) develop a model indicating that wood removal for charcoal production results in the most rapid carbon loss. Savanna burning has been estimated to emit $1.8-15.4 \mathrm{Gt} \mathrm{CO}_{2} \mathrm{e} \cdot \mathrm{yr}^{-1}$, indicating considerable potential for fire management to generate carbon assets (Tennigkeit and Wilkes 2008). Fuel wood is the main source of energy for the majority of the rural population in Sahelian Africa, although it is also combined with alternative sources of energy such as animal wastes or millet stalks (Cecelski 2004). 
In Mali, for example, about $90 \%$ of the energy consumed comes from fuelwood (Bugaje 2006), and thus reducing carbon emissions from this source requires support for developing alternative sources of energy.

Overgrazing as a source of rangeland degradation is a more controversial issue in the Sahelian zone. Global studies indicate that grazing can have either positive or negative impacts on carbon sequestration, depending on climate and management practices (Tennigkeit and Wilkes 2008). Greater awareness of the spatial heterogeneity and temporal variability of semiarid and arid rangelands has resulted in some shifts in thinking on equilibrium/nonequilibrium grazing management. Clearly stocking rates do matter, but the grazing pressure and its timing and duration at any given time, as well as plant recovery periods, are of more consequence than long-term average stocking rates (Savory 1999; Vetter 2005). Comparison of carbon sequestration levels on optimally grazed lands with ungrazed or overgrazed lands yields inconsistent results, because of the diversity of the ecological conditions (Smith et al. 2008).

Restoring Degraded Rangelands. Depending on the degree of severity of degradation, rangeland rehabilitation might include a combination of cultivation abandonment, controlled grazing, erosion control, soil fertility improvement, plant introduction and seed dispersal, and reforestation (Woomer et al. 2004).

Grazing exclusion is an important option for restoring lands that are not yet completely degraded. However, the impact on carbon sequestration is not straightforward. In a literature review of 34 studies involving grazed and ungrazed sites around the world, Milchunas and Lauenroth (1993) reported both decreases $(40 \%)$ and increases $(60 \%)$ in soil carbon as result of grazing exclusion. In the Sahelian region, a simulation of various grazing scenarios showed decreases in carbon storage for both grazed and nongrazed site scenarios, although the nongrazing one resulted in a decline at about half the rate of grazing scenarios (Badini et al. 2007). These variations in results might be driven by historical grazing practices and grazing intensities before and after grazing exclusion (Shrestha et al. 2005) or by a structural relationship linking the ecosystem response to grazing intensities to the level of precipitation level. In particular, Derner and Schuman (2007) show the existence of a threshold in the precipitation gradient where above a certain level of mean annual precipitation $(440-600 \mathrm{~mm}$ according to the soil depth measure in SOC) releasing the grazing pressure results from the rangelands results in a decrease of carbon sequestration, while the opposite is observed in more arid areas.

In a simulation study of Northern Senegal using the Century Model and climatic variables over the period 1960 1999, Woomer et al. (2004) found that desertification control programs that involve excluding livestock and human pressures, replanting nitrogen-fixing trees, and arresting soil erosion results in immediate but modest carbon gains $\left(<250 \mathrm{~kg} \mathrm{C} \cdot \mathrm{ha}^{-1} \cdot \mathrm{yr}^{-1}\right.$ over $\left.20 \mathrm{yr}\right)$, only regaining the 1962 level of system carbon after more than $100 \mathrm{yr}$. Once the woody biomass is totally rehabilitated, then carbon gains are estimated to be $0.8 \mathrm{t} \mathrm{C} \cdot \mathrm{ha}^{-1} \cdot \mathrm{yr}^{-1}$. The study indicates it is considerably more efficient to promote good management of rangelands to avoid degradation, rather than rehabilitating after the fact.
Grazing exclusion generates costs to rangeland users. These costs vary depending on the degree to which forage is important in the feeding strategy employed. In the Sahel, purchased complementary feeds are relatively rarely used, with producers primarily relying on accessible forage. The opportunity costs of implementing rangeland management plans that include exclusion increases with the level of land degradation or resource scarcity (Bardhan 1993). A simulation-based analysis of rotational grazing in the north-central part of Mali (Badini et al. 2007) showed that the total amount of compensation required for establishing a reserve in a highly overgrazed site would need to be three times the compensation required for sites with very low grazing pressure. In the overgrazed site, a total of $1688 \mathrm{~kg} \cdot$ dry matter $^{-1}(\mathrm{DM}) \cdot \mathrm{d}^{-1}$ is needed to compensate producers for foregone forage. In contrast, on the lightly grazed site, only $438 \mathrm{~kg} \cdot \mathrm{DM}^{-1} \cdot \mathrm{d}^{-1}$ is needed. In systems where supplementary feeding is used, such as southern Tunisia where natural forage constitutes only 30 $40 \%$ of the feeding calendar, opportunity costs can be calculated using the market price for feed. One project in South Tunisia compensates herders the equivalent of $\$ 8.3 \cdot \mathrm{ha}^{-1} \cdot \mathrm{yr}^{-1}$ in barley (Prodesud, personal communication, 2007).

Controlled access and limited grazing are alternatives to grazing exclusion that may produce better results (Le Houérou 2006). However, considerable variation in sequestration rates occur here as well (Tennigkeit and Wilkes 2008; see also Follett and Reed in this issue). Compensation costs will be lower than in the case of full exclusion; however, this option generates higher transaction costs in implementing the grazing plan because more sophisticated management practices and monitoring are required.

Increasing Carbon Stocks Above Natural Carrying Capacity. Several types of land use changes may increase carbon stocks on rangelands. Afforestation and reforestation as well as silvopastoral systems are key strategies, generating increases in both biomass carbon and SOC stocks (Lal 2004). These can result in a carbon gain of $41 \mathrm{t} \mathrm{C} \cdot \mathrm{ha}^{-1}$ above the current carbon stocks in the Sahel (Woomer et al. 2004). Tree planting is an activity that is already being undertaken in several areas as part of development programs. A recent survey of 78 villages in Burkina Faso found that $41 \%$ of the villages are already involved in tree planting, with an average of $11 \mathrm{yr}$ of experience with the activity. Under these programs, villages plant 850 trees per year at an average cost ranging between $\$ 0.5$ and $\$ 1.00$ per tree for establishment. One important obstacle for afforestation/reforestation programs is the difficulty of protecting trees from grazing animals, resulting in a very low survival rate of the plantation after the first year of establishment ( $37 \%$ on average, data from a survey in the Seno and Oudalan regions in 2004; Drabo et al. 2006).

As the above discussion indicates, several technical options are available for increasing carbon sequestration and storage on rangelands in West Africa, with a considerable range in the investment and opportunity costs involved, as well as the productivity of carbon sequestration per hectare they may generate. For some management changes opportunity costs may be negative over time, but they involve high investment costs. In summarizing a set of studies on the economic 
feasibility of carbon sequestration activities in rangelands settings, Tennigkeit and Wilkes found that high initial costs may require subsidization, and the ability of households to adopt practices and realize benefits varies with resource endowment (Tennigkeit and Wilkes 2008). As pointed out by many authors, programs that take lands out of production clearly lead to greater opportunity costs in terms of foregone land income than do "working lands programs," where land still generates income from the producers (Wu et al. 2001; Graff-Zivin and Lipper 2008; Zilberman et al. 2008). For example, instituting restricted or seasonal use of a pasture instead of completely restricting use, or planting shrubs or trees that generate additional products or that can be harvested in rotation over time, both enable producers to generate income aside from carbon sequestration payments from the land. The timing and level of opportunity and investment costs producers face in making the desired changes result in specific requirements for carbon financing to actually make the transition feasible.

We also suggest that different categories of land users will be affected by different carbon sequestration programs, depending on the type of land use change or management technique promoted. For instance, should priority be given to the conversion of cropland to rangeland, then farmers will be the main participants. Should the program be oriented toward the improvement of range productivity instead, then herders will be the main participants. Of course, in the Sahel, as across much of West Africa, many households comprise both herders and crop farmers. Additionally, because transhumants may also traditionally use village resources (Niamir-Fuller 1999), their access rights may also be altered by various programs. These features have potentially important implications for the design of carbon sequestration programs, because participation may be based on either private landholdings or communal lands. Given the high level of integration of crop and livestock activities in this region, it is likely that successful programs will be based on supra-household-level aggregations potentially covering both activities on private usufruct plots as well as communal rangeland. Coordination and implementation would thus depend on institutions for promoting collective action. We discuss this issue in more detail after reviewing the functioning of existing $\mathrm{C}$ markets.

\section{CURRENT MARKET FOR CARBON SEQUESTRATION FROM RANGELANDS}

In recent years we have seen a rapid growth in the market for carbon emission offsets as a means of mitigating climate change. One major source of payments is cap and trade programs for emissions regulation such as the Clean Development Mechanism (CDM) of the Kyoto Protocol. However, these markets restrict the use of carbon sequestration for offsetting emissions. At this point only afforestation and reforestation are allowable sources of sequestration; soil carbon sequestration from changes in rangelands is not included. Another potential source of payments for carbon sequestration is the voluntary carbon market. The value of trades here is considerably smaller than the cap and trade sector, but it is growing fast, increasing from an estimated $\$ 90$ in 2006 to $\$ 331$ million in 2007 (Hamilton et al. 2008). It also has a much higher percentage of trades involving carbon sequestration from agriculture: approximately $25 \%$ of the value in this market is for carbon emission reductions from soil carbon (Hamilton et al. 2008).

The prices that are being paid for carbon emission reduction credits vary widely by source of demand and type of offset; however, voluntary market payments are significantly lower than that of cap and trade markets such as the CDM. The Biocarbon Fund of the World Bank uses a reference price of $\$ 4$ per $\mathrm{t} \mathrm{CO}_{2}$ equivalent for sequestration sources of offsets. Note that while potential carbon emission reductions are generally measured in carbon metric tons, payments for carbon emission offsets are generally based on tons of carbon dioxide equivalents; conversion from carbon to carbon dioxide equivalents requires multiplication by a factor of 44/12. The Chicago Climate Exchange (CCX), a voluntary exchange of carbon offsets in the United States that allows soil carbon sequestration from rangeland restoration, has paid between $\$ 1$ and $\$ 5$ per t $\mathrm{CO}_{2}$ (CCX 2008). This exchange issues tradable Carbon Financial Instrument contracts to project owners that commit to increase soil carbon sequestration through grazing land management that employs sustainable stocking rates, rotational grazing, and seasonal use in eligible locations.

Suppliers of carbon emission reduction offsets from carbon sequestration are disadvantaged relative to other sources of carbon offsets due to their reversibility. Carbon stored as a result of sequestration can be released back into the atmosphere with a reversal in the land use change that generated the sequestration: for example, if improved grazing management practices were abandoned. One impact of reversibility has been the development of temporary carbon emission offsets for the CDM, which are sold are lower prices than other offsets. The CCX manages the risk of reversibility by requiring producers to maintain a buffer stock of $20 \%$ of total emission credits.

Transaction costs associated with monitoring and verifying carbon sequestration credits vary by market source and can be quite substantial. Cap and trade programs and many voluntary market exchanges require additionality: the sequestration generated should be additional to what would have occurred under a baseline "business as usual" case. Sequestration projects thus require baseline setting, monitoring, and verification in order to be eligible for payments. The costs of monitoring and verification in soil carbon sequestration projects are substantial, increasing significantly in relative terms for smaller project sizes owing to the large amount of fixed transactions costs. Mooney et al. (2004) estimated per hectare costs of monitoring for a 1000 -ha project at between $\$ 5$ and $\$ 8 \cdot \mathrm{ha}^{-1}$, using data from soil carbon projects in the United States (Mooney et al 2004).

At present the opportunities for selling carbon sequestration from rangelands for emissions offsets are quite limited. One of the issues that is under consideration in United Nations Framework Convention on Climate Change (UNFCCC) negotiations on the future of global climate agreements and mechanisms is mitigation from agricultural sources. One problem of using this source for offsets is that few methodologies for assessing, monitoring, and verifying sequestration from rangelands have been developed (Tennigkeit and Wilkes 2008). Another is concerns about net GHG emissions effects of 
rangeland improvements, which could potentially increase methane and nitrous oxide emissions that would outweigh the benefits from soil carbon sequestration (UNFCCC 2008). The voluntary market is likely to remain an important source of payments for agricultural mitigation; however, lack of methodologies is an issue here as well. In addition, low prices in this market result in low returns to carbon sequestration. Unless prices increase substantially, only carbon-sequestering rangeland management changes that also generate significant increases in the returns to rangeland production are likely to be attractive to producers.

Apart from offsets, rangeland mitigation activities may also be funded by the public sector. Examples here include the Global Environment Facility, which provides support for sustainable land management. In addition, other forms of public sector finance to support mitigation from agriculture could also emerge from current UNFCCC negotiations. Tennigkeit and Wilkes (2008) call for the establishment of a publicly funded trust fund for pilot projects to pave the way for future carbon finance opportunities. Another possibility could be the Adaptation Fund established under the UNFCCC to support adaptation efforts in developing countries. Rangeland management activities that sequester soil carbon can also be an important form of climate change adaptation, by increasing the resilience of the production system. While public sector funds for mitigation and adaptation are several magnitudes lower than the potential that can be tapped in offsets markets, they are likely to involve lower transactions costs because additionality, monitoring, and verification requirements are likely to be less stringent than in the offsets market. Thus this source of funds may be more financially feasible for rangeland projects in areas with weak institutional capacity.

\section{OPPORTUNITIES AND CONSTRAINTS OF CARBON SEQUESTRATION PROGRAMS ON WEST AFRICAN RANGELANDS}

Decades of experience with development projects have shown that improving rangeland management practices in Sahelian Africa is fraught with difficulty. Producers face considerable barriers in adopting practices that generate higher net returns to rangeland management over time. The possibility of external payments for the carbon sequestration benefits associated with rangeland management improvements offers a potential way of overcoming these barriers. However, this implies the need for some innovation in designing carbon sequestration payment programs to meet the financing, production, and risk management needs of producers. In many pastoral areas, markets for credit, insurance, land, and labor are often missing or imperfect. Institutional issues in collectively managing natural resources are another key barrier, as most of the Sahelian rangelands tenure systems fall between a continuum of open access and common property. Experience of improved grazing management under a community-based natural resources management framework in Mali has shown that improving pasture quality and soil carbon sequestration is technically possible, but overcoming institutional challenges is key to successful implementation (Perez et al. 2007; Roncoli et al. 2007). The transactions costs associated with making payments for carbon sequestration to a large number of small producers are a major issue. In the following sections we discuss each of these issues in more detail and review existing literature that highlights both opportunities and constraints for payment for carbon sequestration programs arising from market imperfections, collective management of rangelands, and transactions costs of implementing a payment for environmental services (PES) program.

\section{Relaxing Credit Constraints and Reducing Risk}

Risk and credit constraints are a major barrier to making changes in rangeland management practices. A steady flow of payments for carbon sequestration could be an important means to reduce income risk in this context. Following the large literature on producer response to reduced income risk, this additional "safe" income source may then enable producers to increase purchased inputs per hectare and/or adopt innovative, but initially risky, practices and investments that lead to higher overall incomes from land remaining in use (Just 1974; Feder 1980; Feder et al. 1985; Fafchamps 1992). Even if carbon payment programs lead to a reduction of pasture feed resources, they may increase the attractiveness of investing per animal, which could be particularly beneficial; greater "safe" income could well provide these incentives. It is even possible to think of structuring a payment scheme to be negatively correlated with farm or herd income. Currently there is a great deal of activity in the design and issuance of weather-based index-based insurance contracts for smallholders, which could provide some important lessons for designing carbon payment programs that generate insurance benefits (Osgood 2008). These include the need to find an intermediary that already interacts with smallholders (e.g., a national farmers' association in Malawi) and combining services, and in the case of Malawi combining crop loans and insurance contracts (Hess and Syroka 2005).

Papers by Graff-Zivin and Lipper (2008) and Antle and Diagana (2003) highlight potential benefits to local producers from a well-designed PES program in dynamic contexts. GraffZivin and Lipper (2008) look at the situation where adoption of agricultural production systems that generate soil carbon involve a substantial initial investment and also cause greater income variability in the short to medium term; those authors find that "front-loading" payments increases the viability of the program. Similarly, in Antle and Diagana (2003) the authors consider the dynamics of different investments in soil carbon sequestration in the context of credit market imperfections and high producer discount rates. They show that even where these investments increase both carbon sequestration and individual farmer yields over time, farmers may not adopt, due to credit and investment constraints. Again, the authors find that carbon payment program design to alleviate these constraints is needed to be effective.

These studies are largely concerned with adoption by individuals who have full property rights over the land. Rangelands across the world tend to be accessed, used, and managed under various forms of communal tenure, both de facto and de jure. As we discuss below, the fact that most rangeland is nonprivately held presents both opportunities and constraints on the design of an effective carbon payment program.

\section{Communal Land Tenure and Collective Action}

Carbon payment program design for rangelands needs to take into account the fact that many individuals may have secure, 
private tenure to cultivated plots, while having a certain "degree" of access to rangeland areas (Niamir-Fuller 1999; Goodhue and McCarthy 2000). Additionally, those who have the rights to manage, monitor, and enforce rules regarding these rangelands may well be a different and smaller group than all those who have access rights. As noted above, for instance, transhumants may have traditional access rights to village rangelands, but are not likely to have the same rights to use and manage the resource as do villagers. Many villages also have "buffer" zones of rangelands that are often shared with neighboring villages. Finally, the size of community rangelands (and croplands) may change over time; poor collective management of rangelands may increase incentives for households to encroach on rangelands by appropriating these lands for private crop cultivation activities (McCarthy 2004). While recognizing the importance of multiple overlapping claims, here we concentrate on highlighting the incentives of villagers-who may be both farmers and livestock owners-to participate collectively in provision of ecosystem services stemming from the use and management of communal rangelands.

In the absence of effective collective action, individuals have incentives both to overexploit and to under-invest in pasture resources (Dasgupta and Heal 1980). Well-designed carbon sequestration payment programs can improve incentives to undertake collective action. The literature on managing common pool resources indicates that individual incentives are likely to favor collective action in the following situations: 1) where the returns to making changes in management practices yield greater returns when more people participate, 2) where such investments produce both public and private goods, 3) where monitoring individuals' contributions is relatively easy, and 4) where returns to the investment begin to accrue immediately. For example, investing in shrubs or trees on the common rangeland is easy to verify locally and perhaps even by purchasers; it provides a global public good in terms of carbon sequestration and a local common good in terms of reduced erosion and perhaps better water retention and management. A federated structure may enable small groups to own the shrubs or trees (perhaps with rights to harvest in the future), without necessarily owning the land itself. Alternatively, reducing grazing pressure through controlled grazing is likely to generate public goods in terms of increased biodiversity, reduced soil erosion, and increased biomass. However, benefits to herders in terms of animal productivity depend on everyone abiding by the new limits, and both monitoring and enforcement costs are likely to be very high in order to ensure compliance. The spatial scale required for enforcement, in addition to accounting for all those who have periodic access to the rangeland, is likely to increase these costs still further (Dutilly-Diane et al. 2007).

Heterogeneity among users affects individuals' incentives to comply with carbon payment programs as well as internal costs of collective action. Users might differ in terms of the specific rangeland products they rely on (forage, fuelwood, medicinal herbs), in terms of exploitation levels (herd sizes), the degree of access, use, management, and exclusion rights (primary vs. secondary or tertiary rights holders), in terms of total wealth (those with and without access to outside income), in terms of social or cultural backgrounds, etc. Benefits to producers from participating in various carbon sequestration programs will differ across these different types of users, increasing costs of negotiating among users. Determining the distribution of investment costs is also more difficult in heterogeneous groups. The resulting distribution of costs and benefits to individuals will affect their likelihood of participating in carbon payment programs, and thus the costs of monitoring and enforcement that the group as a whole will have to bear.

Design of carbon sequestration programs must consider the nature and extent of overlapping property rights. Different contracts can be structured to provide services depending on the underlying property rights. For instance, in certain highly degraded areas where large investments are required, or where specific areas of land generate very high rates of carbon sequestration, contracts could be structured to pay current rights holders to accept restrictions or prohibitions on land use under a government-managed arrangement. In areas where monitoring is less difficult, such as through satellite imagery, federated groups of more homogeneous membership could establish shrub and/or tree reserves.

\section{Transactions Costs}

Transactions costs have been identified as a major impediment to the development of payments for carbon sequestration and/ or emission reductions, particularly those involving low-income rural producers (Smith and Scherr 2002; Lipper and Cavatassi 2004; Cacho and Lipper 2006; FAO 2007; Perez et al. 2007). Considering the interaction between local communities and potential purchasers, three broad classes of transaction costs are involved with implementing carbon payment programs: search and negotiation, monitoring, and enforcement costs.

Search and Negotiation Costs. Search and negotiation costs arise from the need to identify willing buyers and sellers and in contract negotiation. These costs can be very high in the case of international payment programs and where isolated, poorer communities whose members have limited education and experience dealing with outsiders are involved. Negotiation costs depend on the legal/contracting framework in place, as well as the negotiation skills of the sellers and buyers. The development of standardized contracts and methods is one way that negotiation costs can be reduced. The CCX has developed a standardized methodology for crediting carbon sequestration from rangelands that greatly reduces the transactions costs of participating in the program (CCX 2008). Nongovernmental organizations (NGOs) have often stepped in as the link between communities and international buyers, effectively reducing both search and negotiation costs. For example, the BioClimate Research and Development Foundation is an NGO that supports local communities in accessing voluntary carbon market for sales of carbon sequestration credits. It provides a standardized system for carbon sequestration projects, which is being applied in the Scolel Té project in Chiapas, Mexico. This project involves over 2000 small farmers providing sequestration through forest management (Plan Vivo 2008). It also utilizes a local NGO to coordinate activities through local networks.

Monitoring Costs. Both the agent purchasing the environmental services as well as the local community will face monitoring costs for carbon sequestration payments, although the nature of 
these will vary by type of purchaser. The cost level depends on the difficulty of compliance verification. Monitoring may involve only an assessment of a change in land use or production system, or an actual assessment of the increase in sequestration. The latter is more accurate but is more expensive to implement. The lack of information on the increase in environmental services generated by changes in practices remains the "Achilles heel" for most PES programs (Pagiola et al. 2005). However, methods to measure carbon sequestration have improved dramatically and continue to do so, and several advances in measurements of soil carbon pool have been made to increase the cost effectiveness in monitoring (Lal 2002). In addition, carbon pools can be monitored on a regional scale using remote sensing of the vegetation cover and land use change, although with limits (Dutilly-Diane 2007 and cites therein). Tschakert (2007) reports that Senegalese farmers participating in a project assessing the potential of soil carbon sequestration payments among smallholders proposed institutions at two levels for monitoring: 1) village-level committees (communautés rurales) to be charged with antitheft measures for trees and animals and 2) intercommunity carbon teams trained in monitoring and measurement techniques to track compliance with carbon payment contracts. In Niger, Roncoli et al. (2007) also found that multilevel institutional structures were necessary to effectively implement sustainable pasture management projects that could also generate soil carbon sequestration. They argue that innovations in natural resource management (NRM) institutions will often be needed for carbon payments projects to be feasible, particularly in areas where traditional institutions are defunct or eroding (Roncoli et al. 2007)

Enforcement Costs. Enforcement costs arise in the case of noncompliance and are related to both local, traditional interpretations of property rights as well as the formal legal framework. Those engaging in the contract, and the legal framework under which the contract is signed, must address the very difficult questions of who has both the responsibility and authority for enforcing compliance, what are the punishments for noncompliance, and who has the authority to enforce punishments.

Whereas search, negotiation, and monitoring costs of carbon sequestration projects might be shared among providers and purchasers, enforcement costs are likely to fall almost entirely on the providers. Groups will have to create legitimate enforcement mechanisms for ensuring compliance among group members and bear the full costs of actual enforcement (McCarthy 2004). Costs of enforcement increase with group size and spatial distribution, because both are likely to be associated with weaker social links and greater likelihood of multiple, and perhaps overlapping, authority structures. Provision of carbon sequestration often requires cooperation among a group of natural resource users to work together in supplying the services. The ability of different individuals to "self-select" into the group of providers will be far more limited than is the case, for instance, with micro-credit groups. This is true in most cases of management of common resources, but it is worth stressing since other authors have already suggested the success of certain "micro-credit" programs as offering a potential solution to structuring carbon contracts in regions with communal property rights.
While there have not been many PES programs established in Africa, a number of programs have been implemented in Latin America and Asia from which to draw insights in interacting with smallholders and reducing the transactions costs they face. In an extensive review of PES programs in Asia, Huang and Upadhyaya (2007) note that many projects have been built around preexisting community-based natural resource management groups, and payment contracts with smallholder providers are generally made to a community-level organization. Rosa et al. (2002) also find that more successful programs structure contracts at the community level. FAO notes that transactions costs can be reduced by increasing project size, utilizing existing institutional capacity, and organizing and provision of standardizing contracting procedures (FAO 2007). All these authors stress the importance of intermediaries in reducing transactions costs facing smallholders and in providing concomitant benefits such as technical training. In both the Latin American and Asian contexts, one of the most attractive benefits to providers is increased land tenure security, though this too may generate internal conflicts that must be managed.

\section{Community-Based Natural Resource Management Projects as an Institutional Base for Carbon Sequestration Projects: Insights From Burkina Faso}

Data from a survey undertaken in 2003 of community-based NRM projects in 78 villages of Northeastern Burkina Faso provide insights into designing efficient institutional arrangements for carbon payment programs (a detailed discussion of the survey can be found in McCarthy 2004). One of the institutional innovations in the area has been the creation of village and intervillage commissions for territorial management (Commissions Villageoises [Inter-Villageoises] de Gestion des Terroirs, CVGT and CIVGT), which represents a devolution of NRM processes. The agrarian and tenure reforms initiated in the 1980s under the revolutionary period had given local communities the responsibility to manage natural resources through CVGT and CIVGT. However, only recently-since 2000-has the Burkinabe government produced implementation decrees to complete the process of the agrarian reform, particularly concerning the institutional aspect of NRM at the rural level. Prior to 2000, some projects (such as the Programme Sahelian Burkinabe, sponsored by the Gesellschaft für Technische Zusammenarbeit [GTZ]) had already initiated the creation of these NRM coordination committees. These organizations had the mandate of coordinating all NRM activities within their area, although their role was still fairly limited at the time of the survey. State-sponsored village committees (includes women's, men's, and mixed groups) are found to be most actively involved in all NRM activities and particularly in erosion control measures. Farmer and herder (professional) organizations also participate in all activities, though to a lesser extent than the village committees. Groups specifically formed for reforestation purposes are found in about $22 \%$ of all communities of the sample.

Until the mid-2000s, the projects bore most of costs of implementing rangeland rehabilitation measures. In addition, they were very active in providing training (Table 1). Community members participated by making in-kind contributions or small cash payments for equipment and seedling purchases. 
Table 1. Project implementation costs for Northeast Burkina Faso: stone bunds and reforestation. ${ }^{1}$

\begin{tabular}{|c|c|c|c|}
\hline Activity & \multicolumn{2}{|c|}{ Cost } & $\begin{array}{c}\text { Farmers' } \\
\text { contribution }\end{array}$ \\
\hline Stone bunds & \multicolumn{2}{|c|}{$\left(\right.$ US\$ $\left.\cdot h^{-1}\right)$} & \\
\hline \multicolumn{4}{|l|}{ Project data } \\
\hline \multirow[t]{2}{*}{ PDL Oudalan: Programme de Développement Local (2005) } & Min & 345 & $3 \%$ \\
\hline & Max & 1035 & \\
\hline \multirow[t]{2}{*}{ PSB/GTZ: Programme Sahel Burkinabé/German Cooperation (2001) } & Min & 37 & na \\
\hline & $\operatorname{Max}$ & 67 & \\
\hline \multirow[t]{2}{*}{ JICA: Japan International Cooperation Agency (2005) } & Min & 748 & $3 \%$ \\
\hline & $\operatorname{Max}$ & 1849 & \\
\hline PAE/S: Projet Agro-écologie du Sahel (2002) & Mean & 161 & $5 \%$ \\
\hline \multicolumn{4}{|l|}{ Bibliographical reference data } \\
\hline AML / FONADES (Kiema et al. 2004) & Mean & 173 & $48 \%$ \\
\hline Oxfam, ARFA (Kiema et al. 2004) & Mean & 108 & $44 \%$ \\
\hline Kiema et al. (2001) & Mean & 48 & na \\
\hline \multicolumn{4}{|l|}{ Reforestation } \\
\hline \multirow{3}{*}{$\begin{array}{l}\text { Project data } \\
\text { PDL Oudalan: Programme de Développement Local (2005) }\end{array}$} & \multicolumn{2}{|c|}{$\left(\right.$ US\$ $\cdot$ plant $\left.^{-1}\right)$} & \\
\hline & Min & 0.53 & $3 \%$ \\
\hline & $\operatorname{Max}$ & 1.07 & \\
\hline
\end{tabular}

${ }^{1}$ Source for project data: Drabo et al. (2006).

${ }^{2}$ na indicates not available.

Villagers' contributions were managed by community-based organizations (CBOs), with or without the collaboration of the village chief. Monitoring and enforcement of community contributions was relatively straightforward. The measures used by $\mathrm{CBO}$ s in cases of noncompliance include stopping the activity, exclusion from accessing improved areas (when held in common), and excluding members from using equipment for private purposes. Recently many of the externally funded projects have ended, and maintenance of the NRM infrastructure and any further investments fully devolved to the CVGTs. However, following a 2007 decree, all responsibilities and funds have been transferred from CVGTs to Village Development Committees (VDCs) in the program of the decentralization process. Because most VDCs are not yet in existence, the villages will conduct a de facto conversion of CVGT into VDCs.

A set of rules for community land management already exists in the Sahelian region of Burkina Faso; these regulate the mobility and access to rangelands areas, the integration of livestock and cropping zones, and the norms for access and use of trees and/or range and grasslands. The actors involved in the monitoring and enforcement vary according to the resource of interest: the state environment agency enforces rules for accessing trees and banning wildfires, together with the local (prefectural) authorities (Table 2). Other rules are managed internally: the chief with the assistance of an executive committee regulates access to grazing areas, while the pastoral chief is strongly involved in making rules regarding hay harvesting. This setting leads to various types of compliance rates and punishments. Data indicate that the severity and regularity of punishment for noncompliance is not a guarantee of full compliance, but regional experience indicates that the establishment of local conventions offers a good framework for coordinating the actions of various actors (Banzhaf et al. 2000).
Since the types of NRM activity that the various organizations deal with vary considerably, appropriate institutions for carbon payment programs will also vary by the strategy for sequestering carbon (e.g., reforestation vs. grazing exclusion projects). Some NRM organizations are already supporting activities that may be very promising for carbon sequestration, such as establishment of transhumance corridors for mobile herders, regulation of cropping encroachment onto rangelands, and control of harvesting (Table 2).

The capacity of local institutions to organize and fund activities is as yet unknown, but they could potentially be the coordinators of carbon sequestration payment programs based on their experience in coordinating, monitoring, and enforcing activities. One potentially problematic issue could arise if decentralization of the responsibilities of the CVGTs to VDCs also results in a reduced capacity for multilevel institutional responsibility, which has been identified as important for smallholder carbon programs in Tschakert (2007) and Roncoli et al. (2007) as cited above.

\section{MANAGEMENT IMPLICATIONS}

Increasing carbon sequestration from the rangelands of West Africa has the potential to generate both global environmental and local economic benefits by contributing to climate change mitigation and increasing productivity and returns to pastoralist production systems. Mobilizing carbon finance to support the adoption of these "win-win" scenarios seems to make good sense, yet low prices and high transactions costs in offsets markets and limited institutional capacity are key barriers to making this link. Two broad strategies can be identified in linking rangelands improvement to carbon finance: 1) developing projects for offsets and 2) linking to public sector 


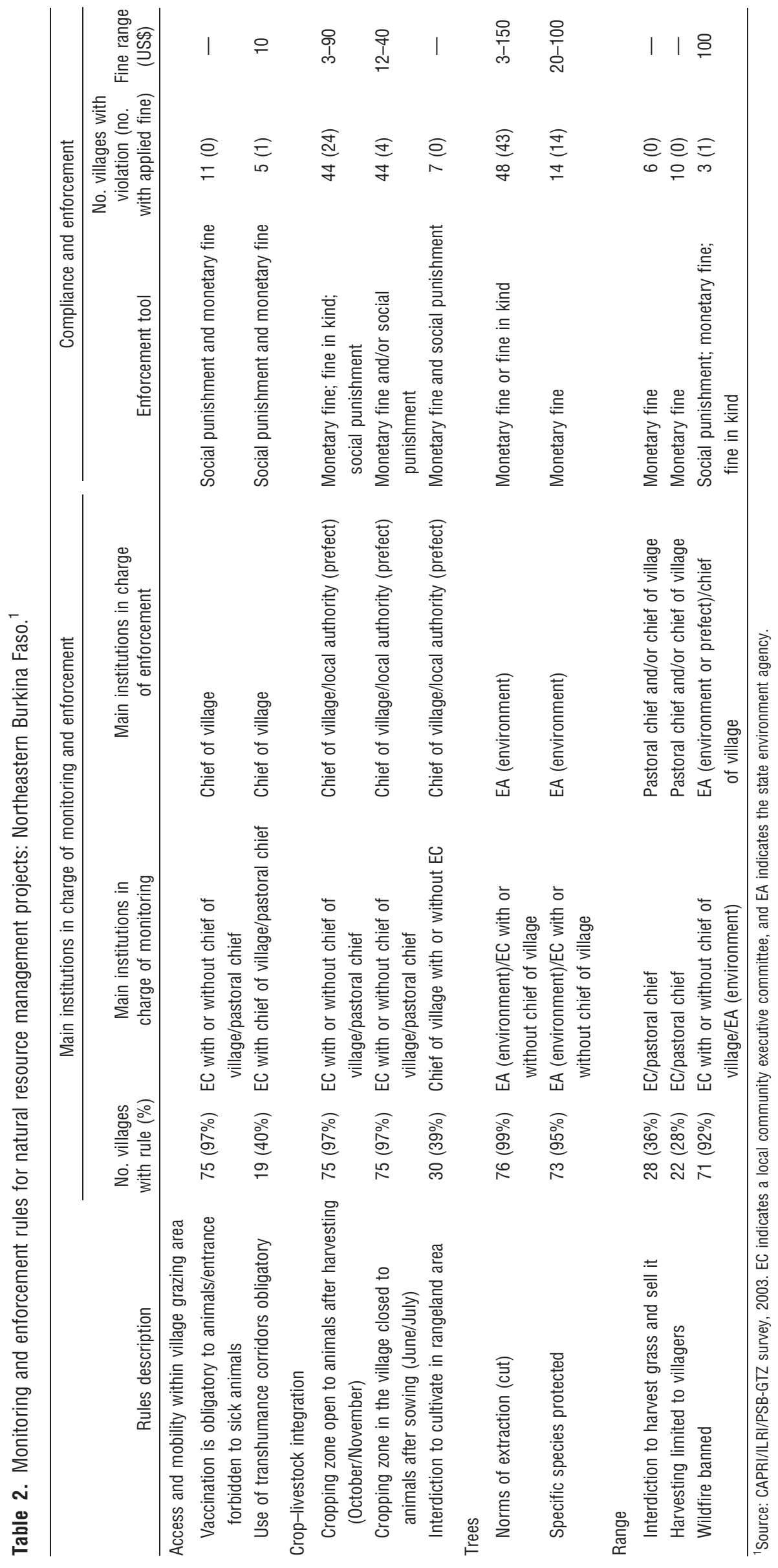


funding. At present opportunities in either case are limited; however, the outcome of current UNFCCC negotiations could potentially create more opportunities for both. Which strategy is most appropriate depends on the specifics of the project, such as the amount of sequestration that can be generated, the investment and opportunity costs involved, and the institutional capacity in place. Two promising management changes are preventing degradation and rehabilitating lightly degraded rangelands, which are relatively low-cost means of sequestering carbon that can also have significant benefits on rangeland productivity. Our analysis indicates that in either case it is important that changes in rangelands management also generate increases in returns to rangeland production, since returns to sequestration are low. One potential way forward is the inclusion of rangeland carbon offsets in cap and trade regimes such as the CDM, which could open the door to higher carbon payments. However, even if this does occur, experience has indicated that only a limited set of projects are likely to be feasible because of high transactions costs and steep barriers to entry. Designing rangelands carbon projects in the voluntary carbon market is another way forward that is more likely to be within reach of a wider range of projects in West Africa. Advances in this market, such as methodology development, are also important for demonstrating what could be done under the regulated cap and trade sector. Finally, linking projects to current public sector funds for mitigation/adaptation or those that may emerge from UNFCCC negotiations will be best for projects with relatively weak institutional capacity and limited sequestration potential.

Effective institutions to minimize transactions costs are a key element to the success of any of these strategies. The case study information from Burkina Faso presented here indicates that local institutions are already in place that have some experience in coordinating natural resource management activities, monitoring, and enforcement-all of which are essential to carbon payment programs. Yet these are likely to need strengthening and some adjustments to meet the specific requirements of carbon programs, and a balance struck between devolving power and decision making to local communities and maintaining the capacity to manage over larger spatial units, which will be needed for rangelands carbon programs. Furthermore, in Burkina Faso as well as other countries in West Africa, there are often multiple land users with overlapping claims of varying degrees. Ensuring that programs do not disenfranchise more vulnerable groups will also be challenging and will require more in-depth understanding at the local level.

\section{ACKNOWLEDGMENTS}

The authors would like to thank two anonymous reviewers for their useful insights and Bernardete Neves for her assistance.

\section{LITERATURE CITED}

AntLE, J. M., And B. Diagana. 2003. Creating incentives for the adoption of sustainable agricultural practices in developing countries: the role of soil carbon sequestration. American Journal of Agricultural Economics 85:1178-1184.

Badini, 0., C. 0. Stockle, J. W. Jones, R. Nelson, A. Kodio, and M. Keita. 2007. A simulation-based analysis of productivity and soil carbon in response to time- controlled rotational grazing in the West African Sahel region. Agricultural Systems 94:87-96.

Banzhaf, M., B. Drabo, and H. Grell. 2000. From conflict to consensus. Towards joint management of natural resources by pastoralists and agro-pastoralists in the zone of Kishi Beiga, Burkina Faso. Securing the Commons 3. London, United Kingdom: SOS Sahel International and the International Institute for Environment and Development. $38 \mathrm{p}$.

Bardhan, P. 1993. Analytics of the institutions of informal cooperation in rural development. World Development 4:633-639.

BatJes, N. H. 2001. Options for increasing carbon sequestration in West African soils: an exploratory study with special focus on Senegal. Land Degradation \& Development 12:131-142.

BATJES, N. H. 2004. Estimation of soil carbon gains upon improved management within croplands and grasslands of Africa. Environment Development and Sustainability 6:133-143.

BoUDET, G. 1975. The inventory and mapping of rangelands in West Africa, 1975. In: Evaluation and mapping of tropical African rangelands. Bamako, Mali: International Livestock Centre for Africa. p. 57-76.

Bugase, I. M. 2006. Renewable energy for sustainable development in Africa: a review. Renewable and Sustainable Energy Reviews 10:603-610.

CACHO, O., AND L. LIPPER. 2006. Abatement and transaction costs of carbon-sink projects involving smallholders. ESA working paper No. 06-13. Agricultural and Development Economics Division of the FAO. Available at: http://www.fao. org/es/esa. Accessed 14 December 2009.

[CCX] Chicago Climate Exchange. Sustainably managed rangeland soil carbon sequestration offsets. Available at: http://www.chicagoclimatex.com/content. jsf?id=1101. Accessed 22 December 2008.

CecelskI, E. 2004. Energy needs, tasks and resources in the Sahel: relevance to woodstoves programs. GeoJournal 7:15-23.

Conant, R. T., and K. Paustian. 2002. Potential soil carbon sequestration in overgrazed grassland ecosystems. Global Biogeochemical Cycles 16:11-43.

Dasgupta, P., and G. Heal. 1980. Economic theory and exhaustible resources. Cambridge, United Kingdom: Cambridge University Press. 516 p.

Derner, J. D., and G. E. Schuman. 2007. Carbon sequestration and rangelands: a synthesis of land management and precipitation effects. Journal of Soil and Water Conservation 62:77-85.

Drabo, B., C. Dutilly-Diane, and N. McCarthy. 2006. An analysis of factors affecting benefits and costs of NRM projects in Northeast Burkina Faso. FAO unpublished report. Rome, Italy: Food and Agriculture Organization. $21 \mathrm{p}$.

Dregne, H., M. Kassa, and B. Rzanov. 1991. A new assessment of the world status of desertification. Desertification Control Bulletin 20:6-18.

Dutilly-Diane, C., N. McCarthy, F. Turkelboom, A. Bruggeman, E. de Pauw, and R. THomas. 2007. Payments for environmental services as a means to combat desertification in CWANA? Reflection on the case of the rangelands. In: C. King, H. Bigas, and Z. Adeel [EDS.]. Desertification and the international policy imperative. Hamilton, Canada: United Nations University. p. 72-82.

FafCHAmps, M. 1992. Cash crop production, food price volatility and rural market integration in the Third World. American Journal of Agricultural Economics 71:90-99.

[FAO] Food and Agriculture Organization. 2006. Livestock's long shadow: environmental issues and options. Rome, Italy: Food and Agriculture Organization. 319 p.

[FA0] Food and Agriculture Organization. 2007. The state of food and agriculture 2007: paying farmers for environmental services. Rome, Italy: Food and Agriculture Organization. $222 \mathrm{p}$.

Feder, G. 1980. Farm size, risk aversion and the adoption of new technology under uncertainty. Oxford Economic Papers 32:263-283.

Feder, G., R. Just, and D. Zilberman. 1985. Adoption of agricultural innovations in developing countries: a survey. Economic Development and Cultural Change 33:255-298.

Goodhue, R., and N. McCarthy. 2000. Fuzzy access: modeling grazing rights in SubSaharan Africa. In: N. McCarthy, B. Swallow, M. Kirk, and P. Hazell [Eds.]. Property rights, risk and livestock development in Africa. Washington, DC, USA: International Food Policy Research Institute. p. 191-210.

Graff-Zivin, J., And L. Lipper. 2008. Poverty, risk and the supply of soil carbon sequestration. Journal of Environment and Development Economics 13:353-373. 
Hamilton, K., M. Suardin, T. Marcello, and G. Xu. 2008. Forging a frontier: state of the voluntary carbon markets 2008. Washington, DC, USA: Ecosystem Marketplace, and New York, NY, USA: New Carbon Finance. 79 p.

Hess, U., AND J. Syroka. 2005. Weather-based insurance in southern Africa: the case of Malawi. Agricultural and Rural Development Discussion Paper No. 13. Washington, DC, USA: World Bank. 67 p.

Homewood, K. 2004. Policy, environment and development in African rangelands. Environmental Science and Policy 7:125-143.

Huang, M., and S. K. Upadhyaya. 2007. Watershed-based payments for environmental services in Asia. Working Paper No. 06-07 (August 2007). Blacksburg, VA, USA: Virginia Tech, Office of International Research, Education and Development. $26 \mathrm{p}$.

[IPCC] Intergovernmental Panel on Climate Change. 2007. Agriculture. In: Climate change 2007. Contribution of Working Group III to the Fourth Assessment Report of the Intergovernmental Panel on Climate Change. Cambridge, United Kingdom: Cambridge University Press. p. 499-540.

Just, R. E. 1974. An investigation of the importance of risk in farmers' decisions. American Journal of Agricultural Economics 56:14-25.

Kiema, A., T. Ouédraogo, A. J. Nianogo, and S. Sanou. 2001. Effets des cordons pierreux et du scarifiage sur la régénération des pâturages naturelles en région sahélienne du Burkina Faso. Revue Science et Technique, Serie Science Nat Agro 25:99-113.

Kiema, A., Y. Samandoulgou, A. Traoré, and B. Drabo. 2004. Etude d'impact des activités de conservation des eaux et des sols de l'ONG Intermon Oxfam. Rapport final. Ouagadougou, Burkina Faso: Intermon 0xfam. 71 p.

LAL, R. 2002. Soil carbon dynamics in cropland and rangelands. Environmental Pollution 116:353-362.

LAL, R. 2004. Carbon sequestration in drylands ecosystems. Environmental Management 33:528-544.

Le Houérou, H. N. 2006. Rationalité, justification. Sécheresse 17:8-9.

LIPPER, L., and R. Cavatassi. 2004. Land use change, poverty and carbon sequestration. Environmental Management 33:374-387.

McCarthy, N. 2004. Managing resources in erratic environments. An analysis of pastoralists systems in Ethiopia, Niger and Burkina Faso. Research report No. 135. Washington, DC, USA: International Food Policy Research Institute. $89 \mathrm{p}$.

Mllchunas, D. G., and W. K. Lauenroth. 1993. A quantitative assessment of the effects of grazing on vegetation and soils over a global range of environments. Ecological Monograph 63:327-366.

Mooney, S., S. Brown, and D. Shoch. 2004. Measurement and monitoring costs: influence of parcel contiguity, carbon variability, project size and timing of measurement events. Report to The Nature Conservancy Conservation Partnership Agreement, Winrock International Ecosystem Services Unit. Arlington, VA, USA: Winrock International. $20 \mathrm{p}$.

Niamir-Fuller, M. [ed.]. 1999. Managing mobility in African rangelands: the legitimization of transhumance. Stockholm, Sweden: Beijer International Institute for Ecological Economics. $240 \mathrm{p}$

Ojima, D. S., D. O. M. Dirks, E. P. Glenn, C. E. Owensby, and J. O. Scurlock. 1993. Assessment of $\mathrm{C}$ budget for grasslands and drylands of the world. Water, Air \& Soil Pollution 70:95-109.

OKAI, M. 1997. Agricultural production, food security and poverty in West Africa In: W. K. Asenso-Okyere, G. Benneh, and W. Tims [EDs.]. Sustainable food security in West Africa. Boston: Kluwer Academic Publishers. p. 14-34.

Oost, K. van, T. A. Quine, G. Govers, S. De Gryze, J. Six, J. W. Harden, J. C. Ritchie, G. W. McCarty, G. Heckrath, C. Kosmas, J. V. Giraldez, J. R. Marques da Silva, AND R. MerckX. 2007. The impact of agricultural soil erosion on the global carbon cycle. Science 318:626-629

OsGood, D. 2008. Climate information, index insurance and climate risk management. Paper presented at the Food Security and Environmental Change Conference, Oxford, United Kingdom, 2-4 April 2008. Available at: http://www.gecafs.org/ FoodConferencePresentations.htm. Accessed 14 December 2009.

Pagiola, S., A. Arcenas, and G. Platals. 2005. Can payments for environmental services help reduce poverty? An exploration of the issues and the evidence to date from Latin America. World Development 33:237-253.

Perez, C., C. Roncoli, C. Neely, and J. L. Steiner. 2007. Can carbon sequestration markets benefit low-income producers in semi-arid Africa? Potentials and challenges. Agricultural Systems 94:2-12.
Plan Vivo. 2008. Plan Vivo. Available at: http://www.planvivo.org/fx.planvivo/ scheme/mexico.aspx. Accessed 22 December 2008.

PRATT, D. C. 1997. Food security in arid rangelands: an assessment of issues and approaches. Report to FAO AGPC. Available at: http://www.fao.org/docrep/ field/382341.htm. Accessed 14 December 2009.

Reid, R. S., P. K. Thornton, G. J. McCrabb, R. L. Kruska, F. Atieno, and P. G. Jones. 2004. Is it possible to mitigate greenhouse gas emissions in pastoral ecosystems of the tropics? Environment, Development and Sustainability 6:91-109.

Ringius, L. 2002. Soil carbon sequestration and the CDM: opportunities and challenges for Africa. Climatic Change 54:471-495.

RoBeRT, M. 2001. Soil carbon sequestration for improved land management. World Soil Resources Report No. 96. Rome, Italy: Food and Agriculture Organization. 58 p.

Roncoli, C., C. Jost, C. Perez, K. Moore, A. Ballo, S. Cissé, and K. Ouattara. 2007. Carbon sequestration from common property resources: lessons from community-based sustainable pasture management in north-central Mali. Agricultural Systems 94:97-109.

Rosa, H., S. Kandel, L. Dimas, and E. Mendez. 2002. Payments for environmental services and rural communities: lessons from the Americas. Amherst, MA USA: Political Economy Research Institute, and New Delhi, India: Centre for Science and the Environment Conference Paper No. 14.16 p.

SAvory, A. 1999. Holistic management: a new decision-making framework. Washington, DC, USA: Island Press. $614 \mathrm{p}$.

Shrestha, G., P. D. Stahl, L. C. Munn, E. G. Pendall, G. F. Vance, and R. Zhang. 2005 Soil carbon and microbial biomass carbon after 40 years of grazing exclusion in semiarid sagebrush steppe of Wyoming. Arid Lands Newsletter 58. Available at: http://gyami.shrestha.googlepages.com/ALNNo.58_Shrestha_ Soilcarbonandmicro.pdf. Accessed 14 December 2009.

Smith, J., AND S. J. ScherR. 2002. Forest carbon and local livelihoods: assessment of opportunities and policy recommendations. CIFOR Occasional Paper No. 37. Jakarta, Indonesia: Center for International Forestry Research. 45 p.

Smith, P., D. Martino, Z. Cal, D. Gwary, H. H. Janzen, P. Kumar, B. McCarl, S. Ogle, F. O'Mara, C. Rice, R. J. Scholes, O. Sirotenko, M. Howden, T. McAllister, G. Pan, V. Romanenkov, U. Schneider, S. Towprayoon, M. Wattenbach, and J. U. Smith. 2008. Greenhouse gas mitigation in agriculture. Philosophical Transactions of the Royal Society B 363:789-813.

Suttie, J. M., S. G. Reynolds, and C. Batello. 2005. Grasslands of the world. Plant production and protection series No. 34. Rome, Italy: Food and Agriculture Organization. $538 \mathrm{p}$.

Swallow, B., AND N. McCarthy. 2000. Property rights, risk and livestock development in Africa: issues and project approach. In: N. McCarthy, B. Swallow, M. Kirk, and P. Hazell [eds.]. Property rights, risk and livestock development in Africa. Washington, DC, USA: International Food Policy Research Institute. p. 1-20.

Tennigkett, T., AND A. Wilkes. 2008. An Assessment of the potential for carbon finance in rangelands. World Agroforestry Center China Working Paper No. 68. Nairobi, Kenya: World Agroforestry Centre. 31 p.

Tiessen, H., C. Feller, E. V. S. B. Sampaio, and P. Garin. 1998. Carbon sequestration and turnover in semi-arid savannas and dry forests. Climatic Change 40:105-117.

Tieszen, L. L., G. G. Tappan, And A. Touré. 2004. Sequestration of carbon in soil organic matter in Senegal: an overview. Journal of Arid Environments 59:409-425.

TSCHAKERT, P. 2007. Environmental services and poverty reduction: options for smallholders in the Sahel. Agricultural Systems 94:75-86.

[UnfCCC] United Nations Framework Convention on Climate Change. 2008. Challenges and opportunities for mitigation in the agricultural sector. FCCC/TP/2008/8, 21 November. Available at: http://unfccc.int/resource/docs/2008/tp/08.pdf. Accessed 14 December 2009.

VetTer, S. 2005. Rangelands at equilibrium and non-equilibrium: recent developments in the debate. Journal of Arid Environment 62:321-341.

Woomer, P. L., A. Touré, and M. Sall. 2004. Carbon stocks in Senegal's Sahel transition zone. Journal of Arid Environment 59:499-510.

Wu, J., D. Zllberman, and B. Babcock. 2001. Environmental and distributional impacts of conservation targeting strategies. Journal of Environmental Economics and Management 41:333-350.

Zllberman, D., L. Lipper, and N. McCarthy. 2008. When are payments for environmental services beneficial to the poor? Journal of Environment and Development Economics 13:255-278. 